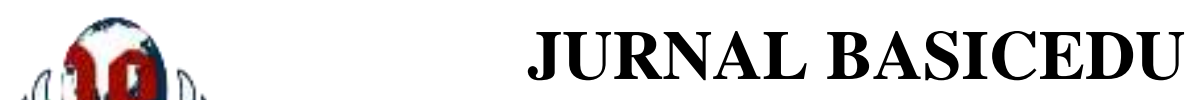

Volume 5 Nomor 5 Tahun 2021 Halaman 4109 - 4119

Research \& Learning in Elementary Education

https://jbasic.org/index.php/basicedu

PAHLAWAN

\title{
Peran Orang Tua dalam Meningkatkan Motivasi Belajar Peserta Didik pada Masa Pandemi Covid 19 di Sekolah Dasar
}

\author{
Arum Sulastri ${ }^{1 凶}$, Masriqon $^{2}$ \\ STKIP PGRI Metro, Indonesia ${ }^{1,2}$ \\ E-mail: arumsulas3@gmail.com ${ }^{1}$, $\underline{\text { masricon@gmail.com }}^{2}$
}

\begin{abstract}
Abstrak
Salah satu sektor yang berdampak dari adanya wabah covid-19 adalah sektor pendidikan, yang menimbulkan alternatif agar pembelajaran tetap berjalan yaitu dengan pembelajaran secara online atau pembelajaran dalam jaringan (daring). Tugas orang tua saat ini menjadi bertambah berat setelah pemerintah memutuskan penerapan kebijakan proses belajar mengajar yang berubah menjadi online yang artinya belajar dari rumah selama pandemi covid-19. Penelitian ini bertujuan untuk mengetahui Peran orang tua dalam meningkatkan motivasi belajar peserta didik pada masa pandemi covid-19. Metode yang digunakan adalah deskriptif kualitatif. Pengumpulan data dilakukan dengan metode observasi, wawancara dan dokumentasi. Teknik analisis data dengan analisis model interaktif yang meliputi reduksi data, penyajian data dan penarikan kesimpulan atau verifikasi. Hasil penelitian yang diperoleh dari Informan 50 Orang Tua Peserta Didik yaitu sebanyak 100\% Orang tua mengecek perkembangan belajar anak, 78\% Orang tua menanyakan tentang materi pembelajaran saat belajar daring, 86\% Orang tua memberikan penghargaan, 56\% Orang Tua memberikan fasilitas, $80 \%$ Orang tua membantu anak menjawab tugas, $66 \%$ Orang tua menyediakan waktu khusus bagi anak belajar, $82 \%$ Orang tua menemani anak ketika belajar, $60 \%$ Orang tua memberikan hukuman, $82 \%$ anak mengalami kebosanan dan $62 \%$ Orang tua mempunyai hambatan proses pembelajaran daring.
\end{abstract}

Kata Kunci: Peran Orang Tua, Motivasi Belajar, Pandemi Covid-19

\begin{abstract}
One of the sectors impacted by the COVID-19 outbreak is the education sector, which poses an alternative to keep the learning going, namely online learning or online learning. The task of parents is now becoming more difficult after the government decided to implement a policy for the teaching and learning process that changed to online, which means learning from home during the covid-19 pandemic. This study aims to determine the role of parents in increasing students' learning motivation during the covid-19 pandemic. The method used is descriptive qualitative. Data was collected by using observation, interview, and documentation methods. Data analysis technique with interactive model analysis includes data reduction, data presentation, and drawing conclusions or verification. The results obtained from the Informants of 50 Parents of Students, as many as $100 \%$ of parents check their children's learning progress, $78 \%$ of parents ask about learning materials when learning online, $86 \%$ of parents give awards, $56 \%$ of parents provide facilities, $80 \%$ Parents help their children to answer assignments, $66 \%$ of parents provide special time for their children to study, $82 \%$ of parents accompany their children when studying, $60 \%$ of parents give punishment, $82 \%$ of children experience boredom and $62 \%$ of parents have obstacles in the online learning process.
\end{abstract}

Keywords: Role of Parents, Learning Motivation, Covid-19 Pandemic

Copyright (c) 2021 Arum Sulastri, Masriqon

Corresponding author :

Email : arumsulas3@gmail.com

DOI $\quad$ : https://doi.org/10.31004/basicedu.v5i5.1504

ISSN 2580-3735 (Media Cetak)

ISSN 2580-1147 (Media Online)

Jurnal Basicedu Vol 5 No 5 Tahun 2021

p-ISSN 2580-3735 e-ISSN 2580-1147 


\section{PENDAHULUAN}

Infeksi Virus Korona disebut Covid-19 (Corona Virus Disease 2019) merupakan virus yang dapat menimbulkan penyakit mulai dari flu hingga menimbulkan penyakit berat dan kematian. Kasus penyakit covid 19 muncul dan menginfeksi manusia pertama kali ditemukan di Wuhan China pada bulan Desember 2019. Virus ini menular dengan sangat cepat dan telah menyebar hampir semua negara, termasuk Indonesia hanya dalam waktu beberapa bulan, rentang waktu Maret 2020 sampai dengan Maret 2021 mencapai 1.347.026 pada 2 Maret 2021, dari jumlah tersebut 1.160.863 dinyatakan sembuh dan 36.518 meninggal dunia.(Wicaksono, 2021).

Pemerintah sudah melakukan berbagai cara untuk menekan angka kematian yang disebabkan adanya covid-19, pemerintah Indonesia menghimbau untuk tetap di dalam rumah dan mengisolasi diri. Pemerintah juga sudah menerapkan aturan Pembatasan Sosial Berskala Besar (PSBB), menerapkan 3M (memakai masker, mencuci tangan, menjaga jarak dan menghindari kerumunan) dan menganjurkan agar setiap individu melakukan vaksinasi covid-19 yang sudah dibeli oleh pemerintah Indonesia. Hal ini dilakukan dengan harapan virus tidak dapat menyebar secara luas dan upaya penyembuhan dapat berjalan secara maksimal. Penyebaran Virus Korona (COVID-19) yang semakin luas ke seluruh dunia menimbulkan aktivitas yang baru diseluruh sektor kehidupan manusia pada saat ini, begitu juga pada Indonesia yang saat ini penyebarannya masih perlu diwaspadai karena semakin banyak penularannya. Menyikapi tersebarnya virus tersebut, pemerintah mengambil kebijakan di segala bidang salah satunya bidang pendidikan. Kementerian Pendidikan, Kebudayaan, Riset dan Teknologi (Kemdikbudristek) pada awalnya memberlakukan kebijakan belajar di rumah dengan sistem pembelajaran jarak jauh melalui metode pembelajaran online. Prinsip kebijakan pembelajaran di masa pandemi covid-19 ini mengutamakan kesehatan dan keselamatan peserta didik, pendidik, tenaga kependidikan, keluarga dan masyarakat yang mempertimbangkan tumbuh kembang peserta didik dan kondisi psikososial dalam upaya pemenuhan layanan pendidikan. Mempertimbangkan kebutuhan pembelajaran, pemerintah melakukan penyesuaian terkait pelaksanaan pembelajaran di zona kuning dan hijau dapat melaksanakan pembelajaran tatap muka dengan menerapkan protokol kesehatan yang sangat ketat, dan bagi zona oranye dan merah dilarang melakukan pembelajaran tatap muka di satuan pendidikan dan tetap melanjutkan belajar dari rumah. Mendikbud menekankan bahwa sekalipun daerah sudah dalam zona hijau atau kuning namun bukan berarti keharusan, otonomi dan prerogatif pemda dan sekolah memberikan izin pembelajaran tatap muka, keputusan akhir ada di orang tua. (Winahyu, 2020)

Berdasarkan UU Nomor 20 Tahun 2003 pasal 1 ayat 1 tentang pendidikan yaitu usaha sadar dan terencana untuk mewujudkan suasana belajar dan proses pembelajaran agar peserta didik secara aktif mengembangkan potensi dirinya untuk memiliki kekuatan spiritual, keagamaan, pengendalian diri, kepribadian, kecerdasan, akhlak mulia, serta keterampilan yang diperlukan dirinya, masyarakat, bangsa dan negara. Dengan adanya tujuan pendidikan nasional tersebut, maka untuk mewujudkannya diperlukan peran dari berbagai pihak yaitu guru, pemerintah, sarana prasarana, dan orang tua. Keluarga tidak hanya ayah dan ibu, yang menjadi pendidik pertama bagi anak ialah orang tua. Orang tua merupakan orang pertama yang memiliki peran sangat besar dalam membina pendidikan anak, karena segala pembelajaran dilakukan dilingkungan keluarga. Peran orang tua dalam mendampingi dan mendidik anak tidak terbatas sebagai orang tua yang hanya memberikan tanggung jawab penghidupan. Orang tua juga berperan sebagai panutan, motivator anak, cermin utama anak, dan sebagai fasilitator anak (Jamaludin, 2013, p. 145)

Orang tua merupakan wadah pendidikan atau sekolah yang pertama dan utama bagi anak, disadari atau tidak oleh orang tua segala tingkah laku sehari-hari yang dilihat, dirasa dan didengar oleh anak merupakan proses belajar bagi mereka. Peran orang tua orang tua dalam kehidupan anak memiliki dampak yang luas selain guru di sekolah, orang tua harus semakin menyadari pentingnya memberikan motivasi belajar yang terbaik pada anak-anak mereka sejak dini dalam membimbing dan mendampingi anak di kehidupan keseharian anak. Menurut (Rumbewas, Laka, \& Meokbun, 2018, p. 201) menyebutkan peran orang tua sangat besar pengaruhnya 
4111 Peran Orang Tua dalam Meningkatkan Motivasi Belajar Peserta Didik pada Masa Pandemi Covid 19 di Sekolah Dasar-Arum Sulastri, Masriqon

DOI: https://doi.org/10.31004/basicedu.v5i5.1504

terhadap keberhasilan peserta didik dalam belajar, tinggi rendahnya pendidikan orang tua, besar kecilnya penghasilan, cukup atau kurang perhatian dan bimbingan orang tua, rukun atau tidaknya kedua orang tua, akrab atau tidaknya hubungan orang tua dengan anak, tenang atau tidaknya situasi dalam rumah, semua itu mempengaruhi pencapaian hasil belajar peserta didik.

Tugas orang tua saat ini menjadi bertambah berat setelah pemerintah memutuskan penerapan kebijakan proses belajar mengajar yang berubah menjadi online yang artinya belajar dari rumah selama pandemi covid 19. Temuan Save the children menunjukkan akibat pembelajaran jarak jauh (PJJ) 40 persen orang tua mengatakan motivasi belajar anak semakin berkurang (Efendi, 2020). Orang tua pada awalnya berperan dalam membimbing sikap serta keterampilan yang mendasar seperti pendidikan agama untuk patuh terhadap aturan dan untuk pembiasaan yang baik, namun perannya menjadi meluas yaitu sebagai pendamping pendidikan akademik (Lilawati, 2020, p. 551). Para orang tua diharuskan untuk memastikan peserta didik untuk melaksanakan kegiatan belajar di rumah masing-masing, membatasi kegiatan keluar rumah, berkoordinasi dengan wali kelas untuk tugas pembelajaran, membantu siswa menerapkan pola hidup bersih sehat (PHBS). Beban yang berat kini ada di pundak para orang tua, penyesuaian untuk memotivasi anak dalam mendampingi dan mengawasi pada saat mengikuti proses belajar di rumah, orang tua sebagai motivator anak harus memberikan dorongan dalam segala aktivitas anak. Menurut (Hero \& Sni, 2018, p. 130) dalam hubungan dengan dunia pendidikan, orang tua adalah salah satu sekolah informal, maka orang tua memiliki andil dan kontribusi yang signifikan terhadap motivasi belajar anak sebagai peserta didik, orang tua juga mampu mendorong atau support anak untuk semakin giat dalam belajar. Dengan demikian harus diakui bahwa motivasi dari orang tua sangat berpengaruh bagi proses pendidikan atau belajar anak.

Motivasi belajar merupakan keseluruhan daya penggerak di dalam diri yang menimbulkan kegiatan belajar, yang menjamin kelangsungan dari kegiatan belajar dan yang memberikan arah pada kegiatan belajar, sehingga tujuan yang dikehendaki oleh subjek belajar dapat tercapai(Sardiman, 2011, p. 75). Motivasi belajar adalah dorongan atau kekuatan yang menggerakkan seseorang untuk melaksanakan kegiatan belajar. Motivasi dibagi menjadi dua yaitu 1) motivasi intrinsik yaitu motivasi yang timbul dari dalam individu sendiri tanpa ada paksaan dorongan orang lain, tetapi atas dasar kemauan sendiri, sedangkan 2) motivasi ekstrinsik yaitu motivasi yang timbul sebagai akibat pengaruh dari luar individu (Winata \& Friantini, 2019, p. 87). Jadi dapat dikatakan bahwa motivasi merupakan sebuah motor penggerak dan menggerakkan seseorang untuk melakukan sesuatu atau kegiatan yang mengarah pada tercapainya suatu tujuan yang dikehendaki, dengan demikian motivasi merupakan hal yang sangat penting yang harus dimiliki setiap orang untuk mencapai tujuan yang ditentukan. Keadaan sebelum pandemi covid-19 peran orang tua lebih menyerahkan pendidikan kesekolah akan tetapi pada saat ini peran orang tua dimasa pandemi lebih mengarah pada pengawasan dan perhatian yang mempengaruhi motivasi belajar peserta didik.

Sekolah Dasar (SD) Alquran Minhajhuth Thullab merupakan SD yang berbasis islam dan full day school (sehari penuh), akibat pandemi covid-19 SD tersebut merubah sistem pembelajarannya menjadi daring dibawah pengawasan orang tua. Berangkat dari pemikiran tersebut, peneliti melihat begitu pentingnya peran orang tua dalam meningkatkan motivasi belajar anak pada masa pandemi covid 19, maka peneliti terfokus pada penelitian dengan judul 'Peran orang tua dalam meningkatkan motivasi belajar peserta didik pada masa pandemi covid19 di SD Alquran Minhajhuttullab Lampung Timur'. Tujuan dalam penelitian ini untuk mengetahui Peran orang tua dalam meningkatkan motivasi belajar peserta didik pada masa pandemi covid-19 di SD Alquran Minhajhuth Thullab Lampung Timur. Urgensi penelitian ini yaitu berdasarkan latar belakang masalah dikemukakan permasalahan utama bahwa tugas orang tua menjadi berat karena adanya pembelajaran online, dan pentingnya peran orang tua dalam meningkatkan motivasi belajar peserta didik pada masa pandemi covid 19 di SD Alquran Minhajhuth Thullab Lampung Timur. 
4112 Peran Orang Tua dalam Meningkatkan Motivasi Belajar Peserta Didik pada Masa Pandemi Covid 19 di Sekolah Dasar-Arum Sulastri, Masriqon

DOI: https://doi.org/10.31004/basicedu.v5i5.1504

\section{METODE PENELITIAN}

Jenis penelitian ini adalah penelitian lapangan (field research) yaitu suatu penelitian yang bertujuan mempelajari secara intensif tentang latar belakang keadaan sekarang dan interaksi suatu sosial individu, kelompok, lembaga dan masyarakat. Pendekatan yang digunakan dalam penelitian ini yaitu menggunakan penelitian deskriptif kualitatif. Penelitian kualitatif merupakan suatu pendekatan penelitian yang mengungkapkan situasi sosial tertentu dengan mendeskripsikan kenyataan secara benar, dibentuk oleh kata-kata berdasarkan teknik pengumpulan data dan analisis data yang relevan yang diperoleh dari situasi yang alamiah (Satori, 2011, p. 25)

Penelitian ini dilaksanakan di SD Alquran Minhajhuth Thullab Lampung Timur pada Tahun 2021, di mana sekolah ini menerapkan sistem pembelajaran secara daring dan luring serta memiliki program-program yang berbeda dengan sekolah lainnya. Subjek dalam penelitian ini adalah para orang tua peserta didik kelas 2 dan kelas 3. Dan Informan dalam penelitian ini adalah kepala sekolah, guru, ketenagakerjaan/ staf di SD Alquran Minhajhuth Thullab Lampung Timur.

Ada beberapa pendapat mengenai tahapan dalam penelitian kualitatif yang dikemukakan oleh para ahli akan tetapi dari keseluruhan pendapat tersebut dikelompokkan ke dalam dua jenis, yaitu yang mengemukakan berdasarkan langkah fisik (Operasional lapangan/fragmentaris) dan yang ditempuh dan berdasarkan langkah berpikir (kerangka berpikir paradigma) penelitian kualitatif(Satori, 2011). Tahapan yang dijelaskan pada gambar alur penelitian tersebut akan digunakan sebagai langkah dalam penelitian sebagai berikut:

\section{Tabel 1}

\section{Langkah Penelitian}

\begin{tabular}{ll}
\hline Memilih kajian Topik & Menentukan topik dengan mengkaji paradigma dan fenomena empiris \\
\cline { 2 - 2 } & Menetapkan fokus inquiry \\
\cline { 2 - 2 } & Menentukan unit analisis/kategori, sub unit analisis/sub-kategori \\
\hline Mengembangkan pertanyaan inquiry \\
\hline Instrumentasi & Menentukan teknik pengumpulan data \\
\cline { 2 - 2 } & $\begin{array}{l}\text { Memilih informan dari tiap unit analisis } \\
\text { Menuiapkan instrumen pedoman observasi/partisipasi/wawancara/studi }\end{array}$ \\
\hline Pelaksanaan Penelitian & Pengurusan izin \\
\cline { 2 - 2 } & Menemui gatekeeper \\
\hline Observasi partisipasi, wawancara, studi dokumen, triangulasi \\
\hline Pengersiapkan catatan lapangan, FGD \\
\hline Reduksi data \\
\cline { 2 - 2 } & Display \\
\hline Hasil Penelitian & Analisis \\
\hline
\end{tabular}

Tabel 2

Petunjuk pengisian:

Instrumen Orang Tua Peserta Didik

Berilah tanda centang $(\sqrt{ })$ pada kolom yang telah disediakan sesuai dengan keadaan yang sebenarnya.

\begin{tabular}{llc}
\hline No. & \multicolumn{1}{c}{ Pertanyaan } & Jawaban \\
\hline \multicolumn{1}{l}{} & \multicolumn{1}{c}{ Ya } & Tidak \\
\hline 1. & Apakah Bapak/Ibu mengecek perkembangan belajar anak setiap hari ketika di rumah? & \\
\hline 2. & $\begin{array}{l}\text { Apakah Bapak/Ibu menanyakan kepada anak tentang materi pembelajaran saat belajar } \\
\text { daring? }\end{array}$ & \\
\hline 3. & $\begin{array}{l}\text { Apakah Bapak/Ibu pernah memberikan penghargaan kepada anak (bisa berupa } \\
\text { hadiah, pujian)? }\end{array}$ & \\
\hline
\end{tabular}


4113 Peran Orang Tua dalam Meningkatkan Motivasi Belajar Peserta Didik pada Masa Pandemi Covid 19 di Sekolah Dasar - Arum Sulastri, Masriqon

DOI: https://doi.org/10.31004/basicedu.v5i5.1504

4. Apakah Bapak/Ibu memberikan fasilitas bagi anak di rumah untuk pembelajaran daring (ruang belajar)

5. Apakah Bapak/Ibu membantu anak menjawab tugas yang dirasakan sulit untuk anak.

6. Apakah bapak/ibu menyediakan waktu khusus bagi anak untuk belajar?

7. Apakah Bapak/Ibu menemani anak ketika belajar di rumah secara daring

8. Apakah Bapak/Ibu memberikan hukuman ketika anak tidak mau belajar

9. Apakah anak mengalami kebosanan dalam pembelajaran daring selama pandemi 19 ini?

10. Apakah ada hambatan dalam proses pembelajaran daring (kuota internet, handphone)

\section{Tabel 3}

Instrumen Wawancara Guru Kelas 1 dan 2

\begin{tabular}{lll}
\hline No. & \multicolumn{1}{c}{ Pertanyaan } & Jawaban \\
\hline 1. & Bagaimana kesiapan bapak/ibu dalam melaksanakan pembelajaran daring! \\
\hline 2. & Bagaimana cara anak mempersiapkan diri agar dapat mengikuti pembelajaran Daring? \\
\hline 3. & Adakah kendala yang Bapak/Ibu alami saat kegiatan pembelajaran daring? \\
\hline 4. & Adakah kendala dari siswa saat kegiatan pembelajaran daring dilaksanakan! \\
\hline 5. & Bagaimana cara guru dalam melakukan presensi saat anak belajar di rumah? \\
\hline 6. & Aplikasi apa saja yang digunakan guru dalam proses pembelajaran Daring saat ini? \\
\hline 7. & $\begin{array}{l}\text { Apakah peserta didik berminat dan termotivasi selama mengikuti pembelajaran } \\
\text { daring? }\end{array}$ \\
\hline 8. & Apakah fasilitas sekolah sudah memadai dalam proses pembelajaran daring? \\
\hline 9. & $\begin{array}{l}\text { Adakah program pembinaan pada pembelajaran daring dan jika ada bagaimana } \\
\text { mekanismenya! }\end{array}$ \\
\hline 10. & $\begin{array}{l}\text { Apakah Bapak/Ibu berkomunikasi dengan orang tua peserta didik terkait } \\
\text { pembelajaran secara daring? }\end{array}$ \\
\hline
\end{tabular}

Teknik analsis data dalam penelitian ini menggunakan analisi kualitatif, di mana analisis dilakukan secara terus menerus dari awal sampai akhir pelaksanaan penelitian. Tahap akhir dari analisis ini adalah mengadakan pemeriksaan keabsahan data, setelah itu mulailah pada tahap penafsiran data dalam mengolah hasil sementara menjadi teori substantif.

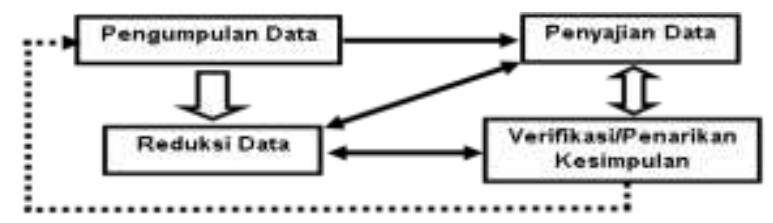

Gambar 1. komponen dalam analisis data (interactive model)

\section{HASIL DAN PEMBAHASAN}

Hasil penelitian yang diperoleh informan yaitu Orang tua peserta didik kelas 2 dan 3 yang berjumlah 50 responden yaitu sebanyak yaitu sebanyak $100 \%$ Orang tua mengecek perkembangan belajar anak setiap hari ketika di rumah, 78\% Orang tua menanyakan kepada anak tentang materi pembelajaran saat belajar daring, $86 \%$ Orang tua memberikan penghargaan kepada anak (bisa berupa hadiah, pujian), 56\% Orang Tua memberikan fasilitas bagi anak di rumah untuk pembelajaran daring (ruang belajar), 80\% Orang tua membantu anak menjawab tugas yang dirasakan sulit untuk anak, 66\% Orang tua menyediakan waktu khusus bagi anak untuk belajar, $82 \%$ Orang tua menemani anak ketika belajar di rumah secara daring, 60\% Orang tua memberikan hukuman ketika anak tidak mau belajar, $82 \%$ anak mengalami kebosanan dalam pembelajaran daring selama pandemic-19, dan 62\% Orang tua mempunyai hambatan dalam proses pembelajaran daring (kuota internet, handphone). Berdasarkan hasil penelitian yang kami lakukan di SD Alquran Minhajhuth Thullab Lampung Timur, peran orang tua terhadap motivasi belajar peserta didik pada masa pandemi covid-19 ini sudah baik, namun perlu di tingkatkan lagi mengenai. memberikan fasilitas bagi anak dirumah untuk pembelajaran daring 
4114 Peran Orang Tua dalam Meningkatkan Motivasi Belajar Peserta Didik pada Masa Pandemi Covid 19 di Sekolah Dasar-Arum Sulastri, Masriqon

DOI: https://doi.org/10.31004/basicedu.v5i5.1504

(ruang belajar) agar orang tua mampu lebih memaksimalkan motivasi peserta didik. Lebih jelasnya dapat dilihat pada bagan sebagai berikut:

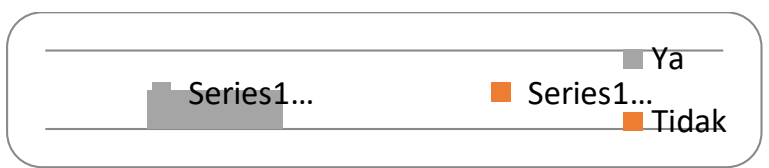

\section{Gambar 2. Persentase Instrumen pada pertanyaan nomor 1.}

Mengecek perkembangan belajar anak setiap hari ketika di rumah sebanyak $100 \%$ menjawab ya dan $0 \%$ menjawab tidak.

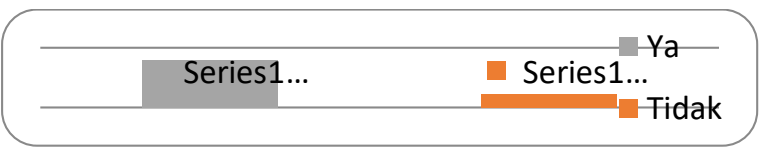

\section{Gambar 3. Persentase Instrumen pada pertanyaan nomor 2.}

Menanyakan kepada anak tentang materi pembelajaran saat belajar daring sebanyak $78 \%$ menjawab ya dan $22 \%$ menjawab tidak.

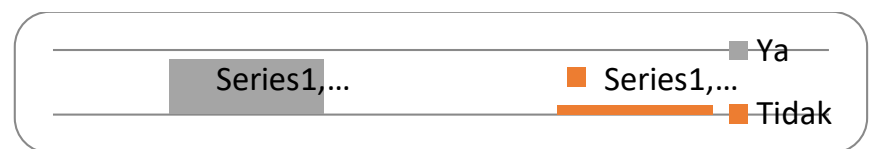

\section{Gambar 4. Persentase Instrumen pada pertanyaan nomor 3.}

Memberikan penghargaan kepada anak (hadiah, pujian) sebanyak $86 \%$ menjawab ya dan $14 \%$ menjawab tidak

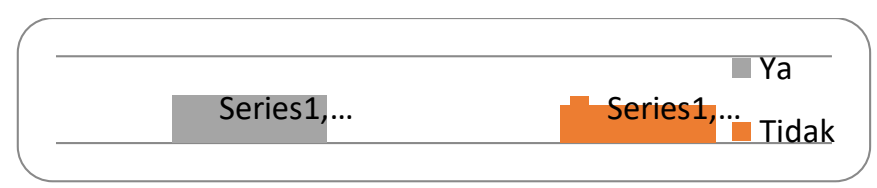

\section{Gambar 5. Persentase Instrumen pada pertanyaan nomor 4.}

Memberikan fasilitas bagi anak dirumah untuk pembelajaran daring (ruang belajar) sebanyak 56\% menjawab ya dan $44 \%$ tidak

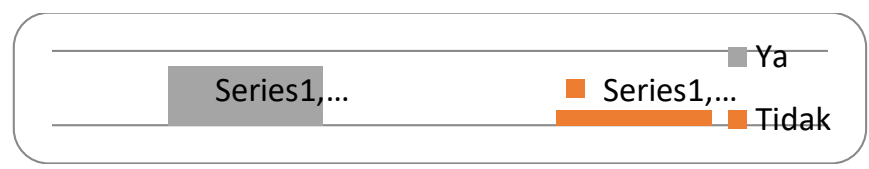

\section{Gambar 6. Persentase Instrumen pada pertanyaan nomor 5.}

Membantu anak menjawab tugas yang dirasakan sulit untuk anak sebanyak $80 \%$ menjawab ya dan $20 \%$ tidak.

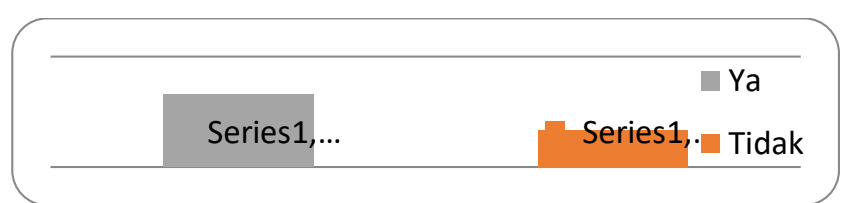

\section{Gambar 7. Persentase Instrumen pada pertanyaan nomor 6.}

Menyediakan waktu khusus bagi anak untuk belajar sebanyak $66 \%$ menjawab ya dan $34 \%$ tidak.

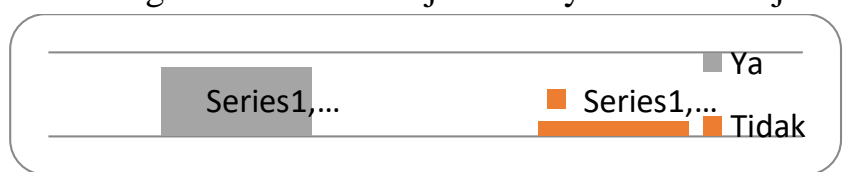

\section{Gambar 8. Persentase Instrumen pada pertanyaan nomor 7.}

Menemani anak ketika belajar dirumah secara daring sebanyak $82 \%$ menjawab ya dan $18 \%$ tidak. 
4115 Peran Orang Tua dalam Meningkatkan Motivasi Belajar Peserta Didik pada Masa Pandemi Covid 19 di Sekolah Dasar-Arum Sulastri, Masriqon

DOI: https://doi.org/10.31004/basicedu.v5i5.1504

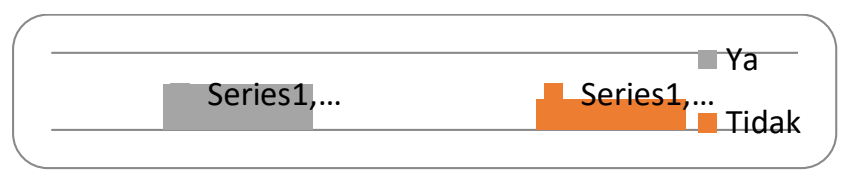

Gambar 9. Persentase Instrumen pada pertanyaan nomor 8.

Memberikan hukuman ketika anak tidak mau belajar sebanyak $60 \%$ menjawab ya dan $40 \%$ tidak.

\begin{tabular}{r|r|}
\hline & \\
\hline Series1,... & Ya \\
\hline & \\
\hline
\end{tabular}

Gambar 10. Persentase Instrumen pada pertanyaan nomor 9.

Anak mengalami kebosanan dalam pembelajaran daring sebanyak $83 \%$ menjawab ya dan $17 \%$ tidak.

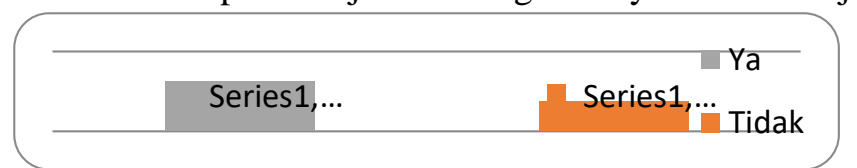

Gambar 11. Persentase Instrumen pada pertanyaan nomor 10.

Hambatan dalam proses pembelajaran daring (kuota internet, handphone) sebanyak $62 \%$ ya dan $38 \%$ tidak

Sedangkan berdasarkan hasil wawancara yang dilakukan kepada guru melalui whatapp dikarenakan adanya Pemberlakuan Pembatasan Kegiatan Masyarakat (PPKM) pada tanggal 20 Agustus 2021 merujuk pada instrumen guru didapatkan hasil sebagai berikut:
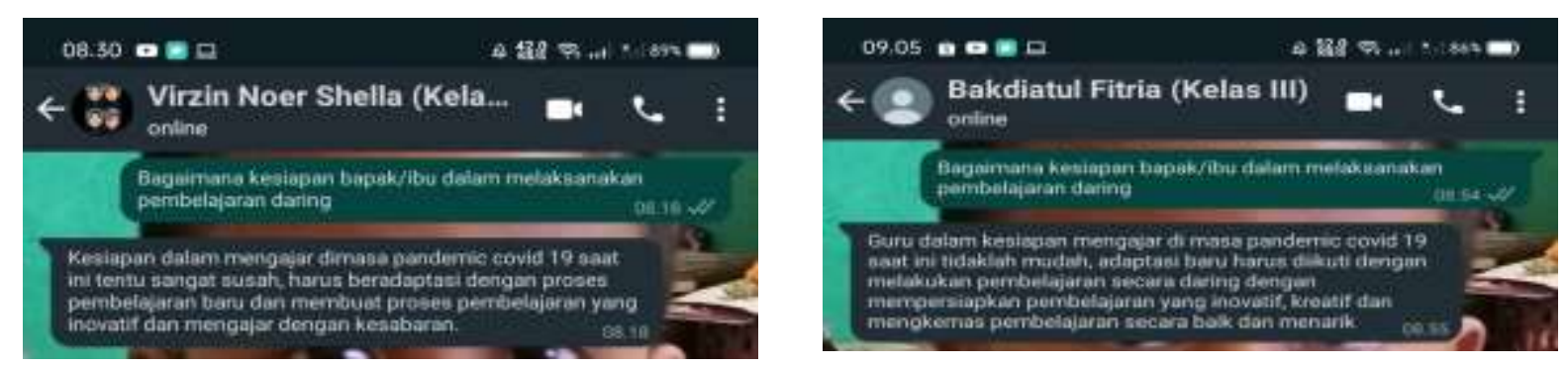

Gambar 12. Hasil Jawaban Guru Instrumen nomor 1. (Guru kelas 2 dan 3)
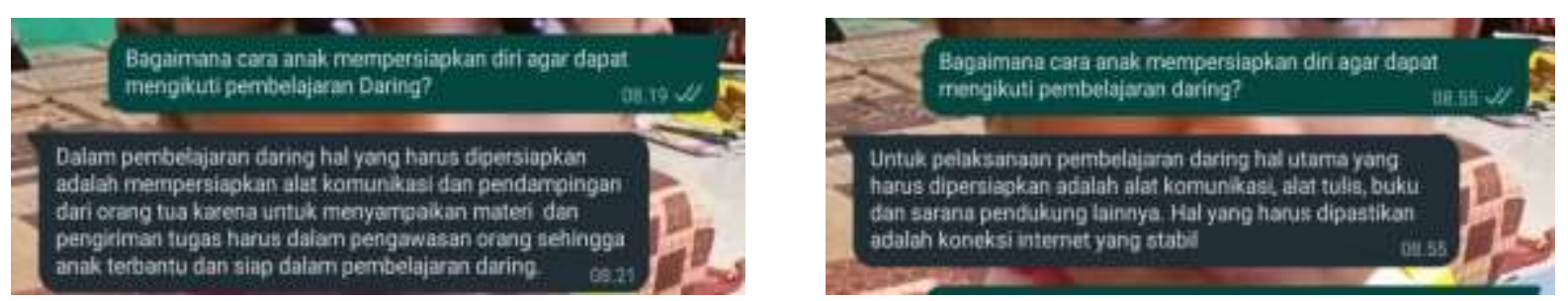

Gambar 13. Hasil Jawaban Guru Instrumen nomor 2 . (Guru kelas 2 dan 3
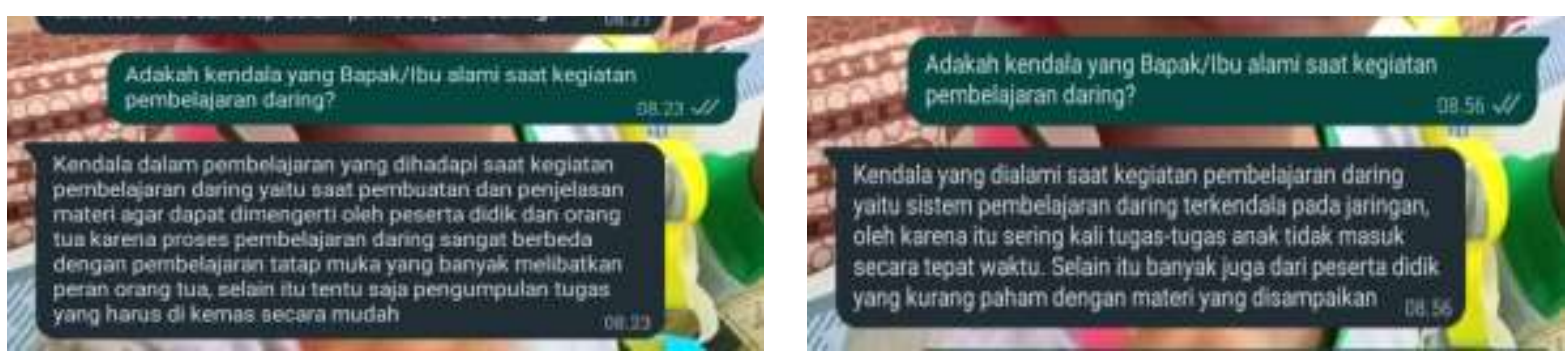

Gambar 14. Hasil Jawaban Guru Instrumen nomor 3. (Guru kelas 2 dan 3) 
4116 Peran Orang Tua dalam Meningkatkan Motivasi Belajar Peserta Didik pada Masa Pandemi Covid 19 di Sekolah Dasar-Arum Sulastri, Masriqon

DOI: https://doi.org/10.31004/basicedu.v5i5.1504
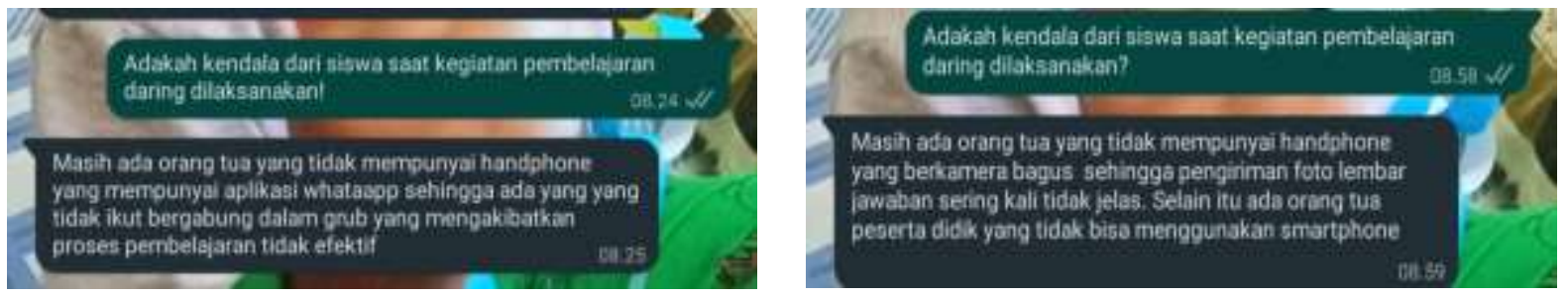

Gambar 15. Hasil Jawaban Guru Instrumen nomor 4. (Guru kelas 2 dan 3)

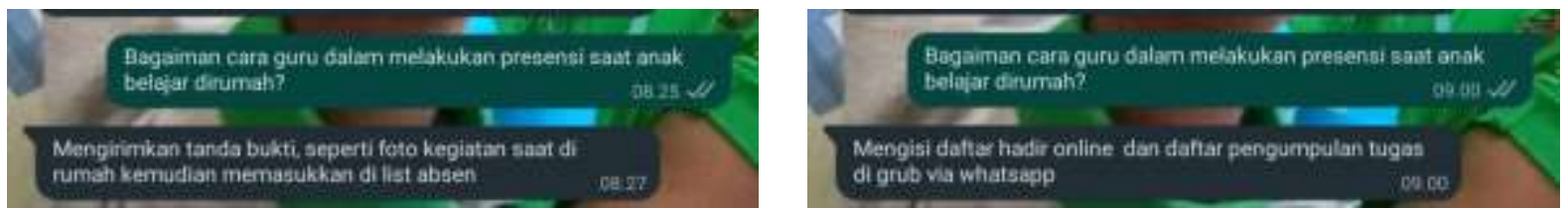

Gambar 16. Hasil Jawaban Guru Instrumen nomor 5. (Guru kelas 2 dan 3)

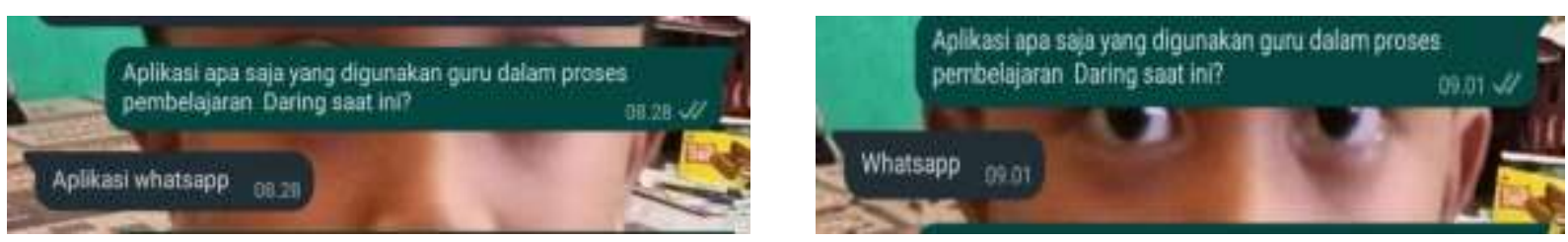

Gambar 17. Hasil Jawaban Guru Instrumen nomor 6. (Guru kelas 2 dan 3)

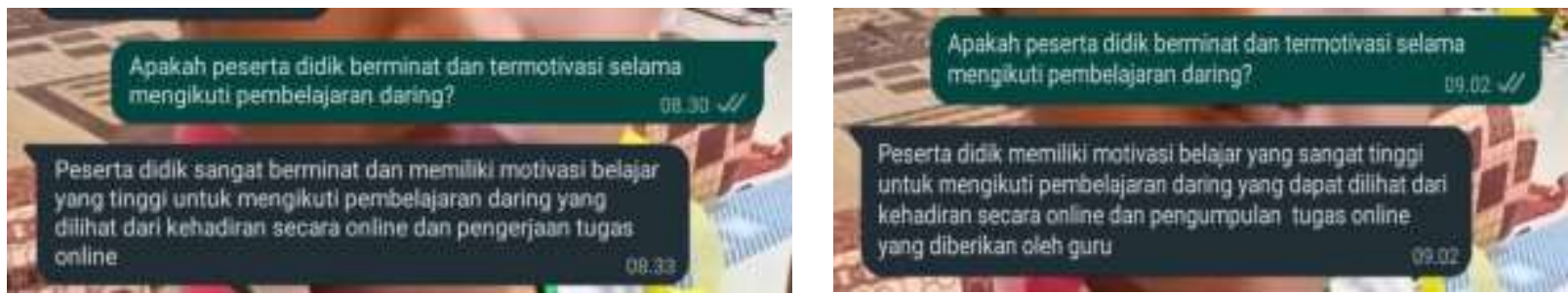

Gambar 18. Hasil Jawaban Guru Instrumen nomor 7. (Guru kelas 2 dan 3)
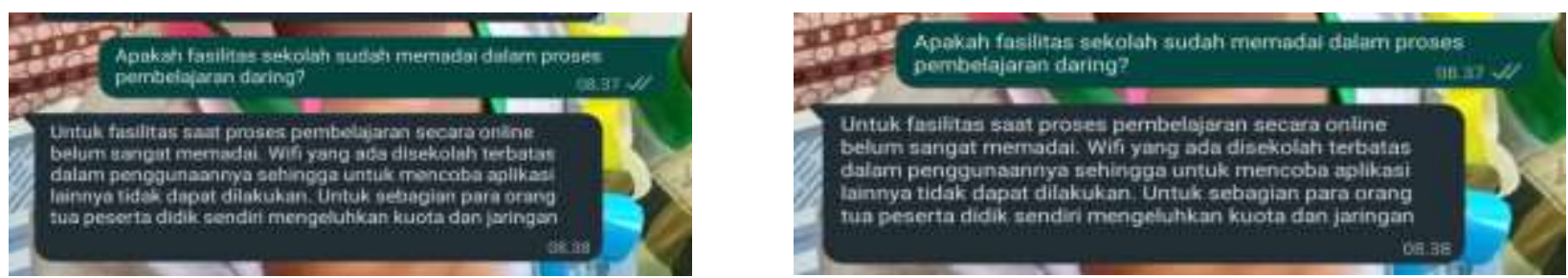

Gambar 19. Hasil Jawaban Guru Instrumen nomor 8. Guru kelas 2 dan 3
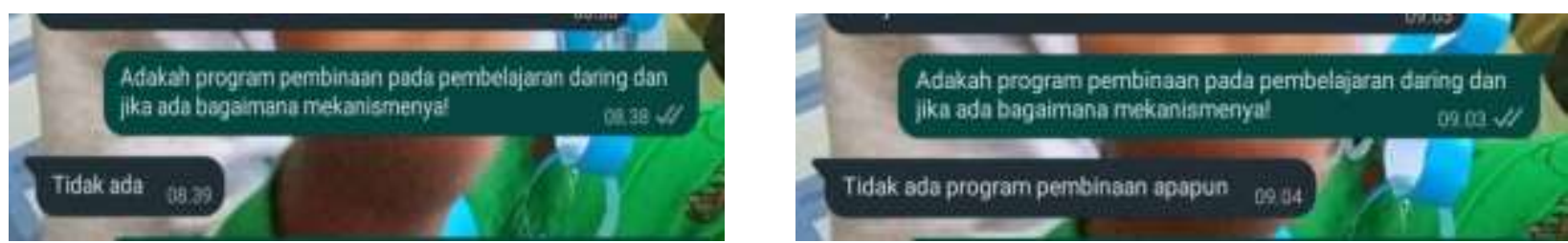

Gambar 20. Hasil Jawaban Guru Instrumen nomor 9.Guru kelas 2 dan 3
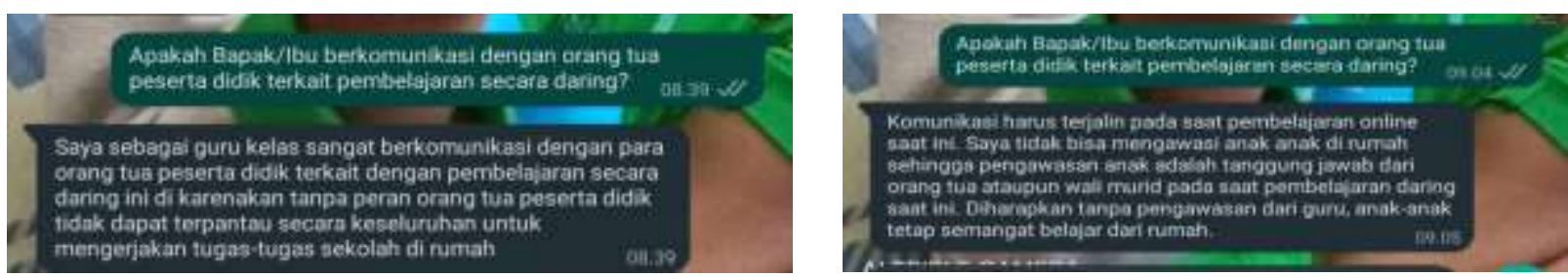

Gambar 21. Hasil Jawaban Guru Instrumen nomor 10. Guru kelas 2 dan 3 
4117 Peran Orang Tua dalam Meningkatkan Motivasi Belajar Peserta Didik pada Masa Pandemi Covid 19 di Sekolah Dasar-Arum Sulastri, Masriqon

DOI: https://doi.org/10.31004/basicedu.v5i5.1504

Keluarga tidak hanya ayah dan ibu, yang menjadi pendidik pertama bagi anak ialah orang tua. Orang tua merupakan orang pertama yang memiliki peran sangat besar dalam membina pendidikan anak, karena segala pembelajaran dilakukan dilingkungan keluarga. Peran orang tua dalam mendampingi dan mendidik anak tidak terbatas sebagai orang tua yang hanya memberikan tanggung jawab penghidupan. Orang tua juga berperan sebagai panutan, motivator anak, cermin utama anak, dan sebagai fasilitator anak (Jamaludin, 2013). Peran orang tua kini diuji dengan adanya keadaan pandemi covid-19 yang melanda negeri ini, dimana mengaharuskan peserta didik belajar di rumah atau stay at home. Menurut (Wardhani \& Krisnani, 2020, p. 54) mengungkapkan dorongan orang tua dan dukungan untuk kegiatan belajar di rumah dikombinasikan dengan keterlibatan guru pada pemberian materi belajar sangat penting untuk keberlangsungan pendidikan anak. Peran orang tua memiliki bagian besar dalam kemampuan anak di lingkup pendidikan, dengan adanya peran orang tua dalam pembelajaran yang dilakukan secara daring dapat melihat kelebihan dan kekurangan untuk belajar.

Selama kegiatan pembelajaran daring, orang tua menjadi garda terdepan untuk mengawasi anak agar tetap memperoleh pendidikan dan pembelajaran, tanpa dukungan orang tua dalam program pemerintah pembelajaran dari rumah tidak akan berjalan dengan baik. Orang tua harus bisa memposisikan dirinya sebagai guru pengajar, pendidik dan sebagai orang tua. Dapat dikatakan bahwa peran orang tua mempunyai andil yang cukup besar dalam meningkatkan motivasi belajar peserta didik dengan menciptakan pembiasaan yang bersifat positif pada kehidupan sehari-hari, sehingga dapat menjadikan anak untuk tetap semangat belajar dimasa pandemi covid-19 dan memperoleh hasil yang diharapkan serta memuaskan. Menurut (Aunurahman, 2012,p. 180) menyebutkan kegiatan belajar yang dilakukan oleh anak tidak terlepas dari adanya dorongan/ motivasi, karena di dalam kegiatan belajar merupakan kekuatan yang dapat menjadi pendorong bagi peserta didik untuk mendaya gunakan potensi yang ada di dalam dan diluar dirinya untuk mewujudkan tujuan belajar. (Adevita \& Widodo, 2021, p. 74) mengungkapkan tumbuhnya motivasi anak untuk belajar didasari oleh ketertarikan terhadap materi ya ng dipelajari dan cara guru mengajar, faktor waktu, suasana lingkungan belajar, adanya keinginan menjadi yang terbaik dengan atau tanpa penghargaan, serta adanya dukungan hangat dari orang tua. Maka dari itu peran orang tua serta guru harus di selaraskan agar dalam masa pandemic covid 19 saat ini peserta didik dapat lebih mengerti tentang keadaan yang harus bersifat waspada dalam kesehatan dan dapat semangat dalam mendapatkan ilmu tidak hanya disekolah tetapi di dalam rumah seperti yang diungkapkan (Dewi, 2019, p. 3379) saat ini sedang terjadi pandemi covid yang merubah kebiasaan belajar siswa dan mempengaruhi motivasi belajar siswa dalam mencapai prestasi belajar sekolah, orang tua harus menyadari ini sehingga kebiasaan belajar siswa tidak terganggu dan tidak mempengaruhi motivasi belajar dalam mencapai sebuah prestasi.

Peranan orang tua selama pembelajaran daring sangat menentukan motivasi anak oleh karena itu orang tua harus pandai mengatur alur belajar anak, jangan membiarkan peserta didik terbebani tugas-tugas yang ada jika tugas anak dikatakan sulit maka orang tua bisa membantu. Selain itu membuat belajar anak menjadi sederhana dengan cara tidak memberikan tekanan pada anak. Dengan orang tua yang selalu mendampingi anak maka dapat meningkatkan kepercayaan diri seorang anak, karena diberikan kasih sayang dan perhatian yang lebih dan rasa aman ketika belajar. Dengan bimbingan guru melalui daring, orang tua harus bisa lebih memaksimalkan hal apa yang diinginkan dari seorang anak agar menjadi lebih baik yang nantinya dapat berpengaruh pada diri anak sendiri ketika mereka belajar. Perlu diketahui kerja sama orang tua dan guru menjadi syarat utama untuk terciptanya keberhasilan belajar secara daring, dorongan dari orang tua dan dukungan untuk melakukan kegiatan belajar di rumah yang disatukan dengan adanya keterlibatan guru pada pemberian materi belajar secara daring maupun luring sangat penting dalam kelangsungan pendidikan peserta didik dimasa pandemi covid 19. Membangun kemitraan yang efektif antara orang tua, keluarga dan sekolah dalam mendukung pembelajaran peserta didik mengarah pada hasil belajar yang lebih baik, sikap terbuka dalam pengalaman belajar akan mempengaruhi niat peserta didik dan lebih mudah dalam beradaptasi menerima pembelajaran secara daring. Guru dan orang tua pada dasarnya sama-sama pendidik, hanya saja keduanya mempunyai peran yang berbeda, guru menjadi pendidik disekolah, sedangkan orang tua menjadi pendidik di 
4118 Peran Orang Tua dalam Meningkatkan Motivasi Belajar Peserta Didik pada Masa Pandemi Covid 19 di Sekolah Dasar-Arum Sulastri, Masriqon

DOI: https://doi.org/10.31004/basicedu.v5i5.1504

rumah, akibat dari covid 19 memaksa keduanya harus ekstra dalam bekerja sama yaitu guru harus meningkatkan kompetensi dalam hal teknologi untuk mengajar daring sedangkan orang tua harus memberikan fasilitas dan pendampingan untuk belajar daring karena tugas yang harus dilakukan guru kini beralih kepada orang tua, hal ini sesuai dengan penelitian dalam jurnal penelitian yang dilakukan (Nida \& Kuntari, 2021, p. 12) menyatakan bahwa orang tua berperan penting dalam pendidikan anak, seperti memotivasi anak, keterlibatan aktif atau langsung dalam mendampingi anak belajar daring selama pandemi covid-19. Adanya peran orang tua dalam memotivasi belajar peserta didik di masa pandemi covid-19 diharapkan dapat memberikan semangat dan dukungan kepada anak dalam melaksanakan pembelajaran sehingga anak memiliki semangat untuk belajar dan memperoleh hasil yang baik. Dalam hal ini peran orang tua di masa pandemi covid 19 berkaitan dengan sikap dan perilaku orang tua terhadap peserta didik agar semangat belajar secara daring.

Hasil wawancara yang dilakukan dengan guru kelas 2 dan kelas 3 yang merujuk pada instrumen guru dapat disimpulkan bahwa dalam masa pandemi covid 19 guru harus tetap berperan dalam melaksanakan tugasnya mengajar dan mendidik meskipun tanpa harus bertatap muka. Guru merupakan fasilitator dalam pembelajaran sehingga dituntut harus mampu menunjukkan kompetensi guru dan mampu menggunakan teknologi untuk mendukung mutu pengajaran yang berdampak pada motivasi anak belajar dimasa pandemi covid 19 saat ini. Tantangan pembelajaran daring yang harus dipahami orang tua yaitu masih ada guru yang belum melek ilmu teknologi, tugas yang tumpang tindih dan padat, serta sarana dan prasarana yang kurang memadai sehingga menghambat pembelajaran daring yang dilakukan oleh guru. Perlu diperhatikan bahwa hasil analisa dalam penelitian tentang peran orang tua dalam meningkatkan motivasi belajar peserta didik pada masa pandemic covid 19 di SD belum dapat dikatakan sempurna, sebab tidak menutup kemungkinan masih banyak kekurangan didalamnya sebagaimana diakibatkan oleh waktu, sumber rujukan, metode dan pengetahuan, serta diharapkan melalui penelitian ini dapat memperkaya khasanah kajian keilmuan dan menjadi pedoman orang tua dan guru dalam meingkatkan motivasi peserta didik khususnya dijenjang sekolah dasar.

\section{KESIMPULAN}

Berdasarkan penelitian yang telah dilakukan dapat disimpulkan bahwa pada masa pandemi Covid 19 peran orang tua diperlukan dalam proses pembelajaran peserta didik. Peran orang tua dalam pendidikan merupakan perilaku yang diharapkan dari orang tua (ayah dan ibu) berupa tanggung jawab dan fungsinya yang harus dilaksanakan sebagai pendidik utama dan pertama bagi anak untuk membentuk kepribadian anak. Sedangkan motivasi belajar merupakan dorongan dalam diri siswa yang menimbulkan kegiatan belajar baik dari dalam maupun luar dirinya sehingga tujuan yang dikehendaki dapat tercapai. Orang tua dapat memberikan motivasi, perhatian, penghargaan, fasilitas, dan dukungan untuk anak saat aktivitas belajar di rumah. Orang tua menjadi garda terdepan untuk mengawal peserta didik agar tetap mendapatkan pendidikan dan pembelajaran. Pentingnya peran orang tua dalam memotivasi peserta didik dalam belajar dapat menjauhkan dari kejenuhan selama pembelajaran daring dan pencapaian hasil belajar akan lebih meningkat.

\section{UCAPAN TERIMA KASIH}

Terima kasih kepada semua pihak yang telah membantu dalam pelaksanaan serta penyusunan penelitian ini yang tidak dapat peneliti sebutkan satu persatu

\section{DAFTAR PUSTAKA}

Adevita, M., \& Widodo. (2021). Peran Orang Tua Pada Motivasi Belajar Anak Dalam Pembelajaran Daring Di Masa Pandemi Covid-19. Jurnal Pendidikan Luar Sekolah, 5(1), 64-77.

Ananda, R. (2020). Program Pengembangan Desa Mitra untuk Meningkatkan Angka Partisipasi Anak Usia Dini pada Lembaga PAUD. Jurnal Abdidas, 1(1), 13-21.

Ananda, R., Fadhilaturrahmi, F., \& Hanafi, I. (2021). Dampak Pandemi Covid-19 terhadap Pembelajaran 
4119 Peran Orang Tua dalam Meningkatkan Motivasi Belajar Peserta Didik pada Masa Pandemi Covid 19 di Sekolah Dasar - Arum Sulastri, Masriqon

DOI: https://doi.org/10.31004/basicedu.v5i5.1504

Tematik di Sekolah Dasar. Jurnal Basicedu, 5(3), 1689-1694.

Aunurahman. (2012). Belajar dan Pembelajaran. Bandung: Alfabeta.

Dewi, T. A. P. dan A. S. (2019). Jurnal basicedu. Jurnal Basicedu, 1(1), 1-9.

Efendi, V. R. | D. A. (2020). Akibat Pandemi, 40 Persen Pelajar Indonesia Kehilangan Motivasi Belajar.

Fadhilaturrahmi, F., Ananda, R., \& Yolanda, S. (2021). Persepsi Guru Sekolah Dasar terhadap Pembelajaran Jarak Jauh di Masa Pandemi Covid 19. Jurnal Basicedu, 5(3), 1683-1688.

Hero, H., \& Sni, M. E. (2018). Peran Orang Tua Dalam Meningkatkan Motivasi Belajar Siswa Kelas V Di Sekolah Dasar Inpres Iligetang. JRPD (Jurnal Riset Pendidikan Dasar), 1(2), 129-139. https://doi.org/10.26618/jrpd.v1i2.1568

Jamaludin, D. (2013). Paradigma Pendidikan dalam Islam. Bandung: CV Pustaka Setia.

Lilawati, A. (2020). Peran Orang Tua dalam Mendukung Kegiatan Pembelajaran di Rumah pada Masa Pandemi. Jurnal Obsesi : Jurnal Pendidikan Anak Usia Dini, 5(1), 549. https://doi.org/10.31004/obsesi.v5i1.630

Nida, A. A., \& Kuntari, S. (2021). Peran Orang Tua Dalam Memotivasi Anak Belajar Daring Selama Pandemi Covid-19. Jurnal Edukasi Dan Sains, 3(1), 93-105.

Rumbewas, S. S., Laka, B. M., \& Meokbun, N. (2018). Peran Orang Tua Dalam Miningkatkan Motivasi Belajar Peserta Didik di Sd Negeri Saribi. Jurnal EduMatSains, 2(2), 201-212.

Sardiman. (2011). Interaksi dan Motivasi Belajar Mengajar. Jakarta: Rajawali Press.

Satori, D. (2011). Metodologi Penelitian Kualitatif. Bandung: Alfabeta.

Wardhani, T. Z. Y., \& Krisnani, H. (2020). Optimalisasi Peran Pengawasan Orang Tua Dalam Pelaksanaan Sekolah Online Di Masa Pandemi Covid-19. Prosiding Penelitian Dan Pengabdian Kepada Masyarakat, 7(1), 48. https://doi.org/10.24198/jppm.v7i1.28256

Wicaksono, A. (2021). Bertambah 6.808 Kasus, Positif Corona Jadi 1.353.834 Baca artikel CNN Indonesia "Bertambah 6.808 Kasus, Positif Corona Jadi 1.353.834" selengkapnya di sini: https://www.cnnindonesia.com/nasional/20210303141420-20-613191/bertambah-6808-kasus-positifcorona.

Winahyu, A. I. (2020). Mendikbud dan Mendagri Bahas Pembelajaran Sekolah dengan Pemda.

Winata, R., \& Friantini, R. N. (2019). Pengaruh Motivasi Belajar Terhadap Prestasi Belajar Matematika Siswa Kelas VIII SMPN 1 Kuala Behe. JIPM (Jurnal Ilmiah Pendidikan Matematika), 7(2), 85.

https://doi.org/10.25273/jipm.v7i2.3663 